\title{
JOURNAL.RU
}

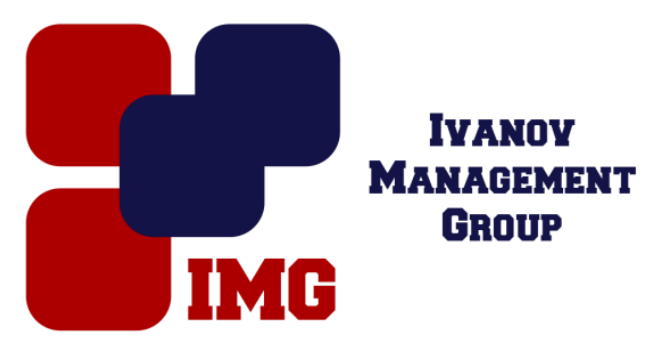

Полихрониди А.П. Финансовый Университет при Правительстве РФ Москва, Россия

doi: 10.18411/1j-31-05-2017-61

idsp 000001:1j-31-05-2017-61

\section{Основные проблемы антикризисного банковского менеджмента и пути их решения}

\section{Аннотация}

В статье раскрываются основные проблемы антикризисного банковского менеджмента на сегодняшний день. Приведены примеры данного вопроса с помощью мировой и отечественной практики. На основе анализа ключевых проблем, автором статьи предложены меры и действия по их ликвидации и улучшению уровня качества антикризисного банковского управления.

Ключевые слова: антикризисный банковский менеджмент; антикризисное управление; банковская система; банковский бизнес; деятельность коммерческого банка.

\section{Annotation}

The article reveals the main problems of anti-crisis banking management to date. Examples of this issue are given with the help of world and domestic practice. Based on the analysis of key problems, the author of the article proposed measures and actions to eliminate them and improve the quality of the anti-crisis banking management.

Keywords: anti-crisis banking management; crisis management; banking system; banking business; activity of a commercial bank.

Эффективность деятельности банковской системы - одна из ключевых условий развития экономики каждой страны. В случае, возникновения локального или системного банковского кризиса, существует риск того, что данная тенденция передастся и другим отраслям экономики. В зависимости от этого, вопросы и 
проблемы антикризисного банковского менеджмента становятся актуальной темой обсуждения современного мира экономической науки.

Многие коммерческие банки переживают ситуации, в которых их финансовая надежность находится в зоне риска, а кредитный портфель становится проблемным, по вине не контролированного риск-менеджмента или из-за ухудшения внешней экономической конъюнктуры. В таком случае, руководство коммерческого банка прибегает к инструментам антикризисного управления, целью которых является ликвидация угрозы, предостережение от приближающегося кризиса и стабилизация коммерческой деятельности кредитной организации.

В целом, антикризисное управление банком можно разделить на три основных этапа:

- диагностика и подготовка;

- профилактика;

- работа в условиях кризиса и дальнейший выход из него.

Исходя из этого, каждый этап антикризисного банковского управления включает в себя отдельные инструменты и задачи, решение которых необходимо для ликвидации возникшей проблемы на стратегическом уровне. Но, в независимости от желания банковского менеджмента и его сотрудников, возникают ситуации, во время которых, проявляются новые проблемы под видом невозможности ликвидации кризиса, поиска альтернативных путей его решения, или более того, антикризисное банковское управление приводит к усугублению возникшей проблемной ситуации в кредитной организации.

Кроме того, анализируя современные тенденции развития банковской системы в той же России, мы можем выделить общую характеристику для антикризисного менеджмента многих банков. Она заключается, как правило, именно в проявление этих проблем, пути решения которых будут разобраны в конце статьи.

Основными примерами проблем российского антикризисного банковского менеджмента будут:

- отсутствие поддержки со стороны «стейкхолдеров»;

- высокие уровни процентных ставок, что повышает риск кредитных и депозитных операций банков;

- отсутствие либерализации банковского сектора страны;

- законодательные «провалы». 
Но, помимо этих проблем, которые можно встретить во многих странах мира, стоит выделить примеры и из зарубежной практики. Финанситы Дж. Бойд и М. Гертлер выдвинули и исследовали такую проблему банковской системы, как «слишком велик, чтобы обанкротиться». Ее суть склоняется к ситуации, когда банкротство крупного банка вызывает банковскую эпидемию и поражает всю банковскую систему. Особенно это очевидно в развивающихся и странах с переходной экономикой, кредитные системы которых в основном представлены несколькими крупными банками. Данная проблема может быть и на территории России, ведь в нашей стране есть те банки, банкротство которых может стать причиной не только банковского кризиса, но и всей экономической рецессии. Примером такой проблемы выступает и мировой финансовый кризис 2008 - 2009 годов, когда из-за банкротства крупнейшего инвестиционного банка США начался крупнейший кризис за последние десятилетия.

Примером выхода из сложившейся ситуации может быть страхование банковских вкладов обанкротившегося банка со стороны правительства и регулятора. Но, наилучшим вариантом, будет, скорее всего, финансирование банка для докапитализации, а также, официальное уведомление о том, что все вклады клиентов будут застрахованы в случае окончательного банкротства кредитной организации.

Другая проблема, характер возникновения которой мировой банковский рынок, является введение «рыночной дисциплины». Финансист М. Фланнери определил и обосновал необходимость рыночной дисциплины с выделением основных моментов, влияющих на эффективность функционирования кредитной системы. По его мнению, многие инструменты пруденциального управления, как, например, условия закрытия банка, дают четкое видение ситуации о деятельности кредитного института и позволяют субъектам ссудного рынка принимать оптимальные решения. Между тем кредитные институты всеми возможными путями пытаются утаить необходимую информацию как от пруденциальных управляющих, так и от общественности, чтобы избежать ограничений на проводимую деятельность. В этих целях вводится понятие «рыночная дисциплина».

Примером выхода из возникшей проблемы может быть история Аргентины, которая в конце 90-хх годов столкнулась с данной ситуацией. Для того чтобы ввести более рациональные пруденциальные нормы, правительство страны создало кредитное бюро, которое обязало всех банков выпускать облигации с полученным рейтингом, обновление которого было раз в год. С помощью такой 
системы, общественность и правительство могло следить за реально происходящими делами аргентинских банков.

Возвращаясь к современным проблемам отечественного банковского антикризисного менеджмента, выделим инструменты и действия, с помощью которых можно найти пути их решения (таблица 1).

Таблица 1

Пути решения основных проблем антикризисного банковского менеджмента в России.

\begin{tabular}{|c|c|}
\hline Проблемы & Пути решения \\
\hline $\begin{array}{c}\text { Отсутствие поддержки со стороны } \\
\text { стейкхолдеров }\end{array}$ & $\begin{array}{c}\text { Усовершенствовать корпоративное управление банками. Внедрить } \\
\text { инструменты КСО. }\end{array}$ \\
\hline $\begin{array}{c}\text { Высокие уровни процентных ставок } \\
\text { Антилиберальное регулирование } \\
\text { банковским сектором }\end{array}$ & $\begin{array}{c}\text { Смягение денежно-кредитной политики Банком России через } \\
\text { процентный канал трансмиссионного механизма. }\end{array}$ \\
\hline Саконодательные «провалы» & $\begin{array}{c}\text { Улучичитит законодательную базу России. Внести новые } \\
\text { законопроекты, учитывающие интересы всех субъектов банковской } \\
\text { деятельности страны. Отменить решения, вызывающие спорные } \\
\text { моменты. }\end{array}$ \\
\hline
\end{tabular}

С помощью мер действий, описанных в таблице 1, возможна ликвидация основных проблем, с которыми сталкиваются российские банковские менеджеры. Стоит не забывать о том, что антикризисное управление в банковском секторе невозможно без участия государственной руки и помощи. В случае неудачи при решении локального кризиса, существует вероятность системного банковского кризиса, что приводит к рецессии развития экономики страны.

1. Современные проблемы антикризисного управления банковской системы. URL: http://economics.studio/finansovyiy-krizis/sovremennyie-problemyi-antikrizisnogo51748.html (дата обращения 20.05.2017).

2. Хогарт Г., Рейдхилл Дж., Синклер П. Разрешение банковских кризисов: основные инструменты и издержки // банки: мировой опыт. - 2009. - № 5.

3. Садыкова А. Э. Основы антикризисного управления в коммерческом банке // Экономика, управление, финансы: материалы IV Междунар. науч. конф. (г. Пермь, апрель 2015 г.). - Пермь: Зебра, 2015. - С. 91-93. 